\title{
Haematological and Biochemical Effects of Metalaxyl Fungicide on Albino Mice
}

\author{
Wael M. Al-Amoudi \\ Biology Department, Faculty of Applied Science, Umm Al-Qura University, Makkah, Saudi Arabia
}

\begin{abstract}
Metalaxyl is a benzenoid fungicide used to control fungal diseases. The aim of this work is to investigate the effect of metalaxyl on haematological and biochemical parameters in male albino mice. In this study, animals were divided into two groups. The animals in the first group $(20$ mice) were given metalaxyl orally through a stomach tube at a dosage of $1 / 10$ of the LD50 (which was equivalent to $130 \mathrm{mg} / \mathrm{kg}$ body weight) at a rate of three times per week for 4 continuous weeks. The second group was treated as a control in which the animals $(20$ mice) were given water orally. Treating mice with metalaxyl for 2 and 4 weeks induced a significant decrease in the RBC count (5.2 \pm 0.24$)$, haemoglobin content (11.5 \pm 2.3$)$ and the number of blood platelets $(543 \pm 15.3)$. In contrast, metalaxyl treatment induced a significant increase in the WBC count (5.8 \pm 0.4$)$. Serum triglyceride and cholesterol levels also increased while total protein and albumin levels decreased in the treated animals. Additionally, metalaxyl treatment resulted in a significant increase in the levels of transaminases, ALT and AST enzymes. The data also revealed a significant increase in serum creatinine in response to metalaxyl toxicity, which might be due to impaired kidney function resulting from fungicide exposure. It was concluded that these metalaxyl effects could be attributed to fungicide-induced oxidative stress, which in turn leads to signs of toxicity. This result was confirmed by other authors who obtained similar results by observing the effects of some fungicides. The premise of this study was that fungicides must be examined for their possible adverse effects on animals and humans before their application to agricultural fields.
\end{abstract}

Keywords Metalaxyl, Mice, Haematological Parameters, Biochemistry, Transaminases

\section{Introduction}

Pesticides are used extensively throughout the world to control agricultural pests and protect public health. Although these chemicals have many beneficial purposes, they can also cause adverse effects in both humans and animals. Pesticides have chronic health effects both as the sequelae of acute poisonings and through chronic exposure. Many studies have documented the adverse health effects of pesticide exposure on humans. There is also convincing evidence that pesticides play a role in human cancers. For example, epidemiological studies have linked insecticide exposure in the home to the development of brain cancer and leukaemia in children. There are several areas of concern that need to be extensively investigated. These chemicals are widely used in industry, agriculture, home and gardens for many different purposes, including the protection of seed grain during storage and germination[10]. Individuals who are exposed to these chemicals include agricultural workers, those living in proximity to farms/orchards or consumers

\footnotetext{
* Corresponding author:

wmamoudi@uqu.edu.sa (Wael M. Al-Amoudi)

Published online at http://journal.sapub.org/ajb

Copyright (C) 2012 Scientific \& Academic Publishing. All Rights Reserved
}

who are exposed to pesticide residues in food[5]. Metalaxyl is a systemic benzenoid fungicide belonging to the most widely known member of the amide group. It is used in foliar spray mixtures for tropical and subtropical crops, as a soil treatment for the control of soil-borne pathogens, and as a seed treatment to control downy mildews, fungal diseases on fruits, cotton, soybeans, peanuts, ornamentals and grasses[10]. Metalaxyl is reported to have hazardous effects on mammalian animals[39].[15] reported that metalaxyl has cytogenetic effects on human and animal chromosomes only in vitro but not in vivo.[40] has also reported that feeding mice with metalaxyl over the long term induced hepatic injury.[25] has indicated that this chemical could lead to the development of cocarcinogenic potential in Swiss albino mice. Metalaxyl caused dose-dependent bradycardia, and at higher doses ( 250 and $300 \mathrm{mg} / \mathrm{kg}$ body weight), the sustained bradycardia led to cardiac arrest[23].[37] has reported that metalaxyl induced histological and biochemical alterations in the liver of albino mice. Moreover,[9] found that imidacloprid and metalaxyl induced in vitro micronucleus formation and sister chromatid exchange induction in human lymphocytes as well as in vivo micronucleus induction in the polychromatic erythrocytes of rat bone marrow, both separately or in combination with one another. Apoptosis and bax expression were observed in the hepatocytes of mice 
that were treated with metalaxyl[35]. In addition, residues of buprofezin, chlorpyriphos, metalaxyl, and myclobutanil were detected in incurred grape and wine samples[7]. The present study was undertaken to examine the effects of metalaxyl-induced stress on the haematological and biochemical activities of albino mice, as indicated by haemoglobin content, the number of blood platelets, and WBC count as well as serum triglyceride, cholesterol, total protein, albumin and creatinine levels. There were also analyses of the changes in transaminases, ALT and AST enzyme levels.

\section{Materials and Methods}

\subsection{Animals and Treatments}

Male albino mice (Mus musculus) weighing $20 \pm 5 \mathrm{~g}$ were obtained from the animal house of King Abdel Aziz University, Jeddah, Saudi Arabia and then housed in plastic cages $(40 \times 30 \times 16 \mathrm{~cm})$ in the laboratory at a constant temperature $\left(22 \pm 1^{\circ} \mathrm{C}\right)$ for at least one week before and during the experimental work period. They were maintained on a standard rodent diet, and water was available ad libitum. All experiments were performed in compliance with a guide for the care and use of laboratory animals (National Research Council, 1985). Animals were divided into 2 experimental groups.

Group 1: Animals in this group (20 mice) were given metalaxyl orally using a stomach tube and a dose level of $1 / 10 \mathrm{LD} 50$ (130 mg/kg body weight) three times per week for 4 continuous weeks.

Group 2: Animals in this group were the controls. All animals (20 mice) were given water orally.

\subsection{Biochemical Assays}

For the haematological study, blood was collected from both the control and treated animals after 2 and 4 weeks of treatment. The haematological parameters evaluated were the following: red blood cell count (RBC), haemoglobin value $(\mathrm{Hb})$, white blood cell count (WBC) and blood platelet number, which were measured according to[8]. For the biochemical study, sera were obtained by centrifuging the blood samples and storing them at $20^{\circ} \mathrm{C}$ until the assays could be completed. Total protein concentration was estimated by the method in[18], cholesterol levels were determined in the manner of [31], triglyceride levels were determined according to the technique of[12], and creatinine and albumin levels were determined using the methods in[14]. Aspartate aminotransferase (AST) and alanine aminotransferase (ALT) levels were determined colourimetrically according to[29].

\subsection{Statistical Analysis}

The results were expressed as the mean $\pm \mathrm{SD}$ of each different group. The differences between the mean values were evaluated by ANOVA, which was followed by
Student's t test that was carried out using the Minitab 12 computer program (Minitab Inc., State College, PA).

\section{Results and Discussion}

The data in table (1) show that there was a gradual decrease in erythrocyte count, haemoglobin content and the number of blood platelets in mice treated with metalaxyl. After 4 weeks of treatment, this decrease was statistically significant. In contrast, the leukocyte count was significantly increased after the fourth week of treatment with metalaxyl. These results are in agreement with those obtained from previous studies of the haematological effects of fungicides on mammalian animals.[13] reported that rats that were fed diets containing thiophanate-methyl fungicide at doses of 0 , $12.8,64,320,1600$, or $8000 \mathrm{ppm}$ for six months demonstrated a decreased erythrocyte count and lower haemoglobin content. Increased leukocyte counts were observed frequently at $6000 \mathrm{ppm}$. Repeated high doses of carbendazim fungicide were associated with liver toxicity and adverse effects on blood cells and in rats[22].[1] showed that male dogs that were fed capsules containing thiophanate-methyl fungicide showed decreases in their total erythrocyte counts as well as their haemoglobin and haematocrit values at the highest dose.[4] noted that a blood analysis of rabbits treated with lambda-cyhalothrin revealed a significant decrease in red blood cell and white blood cell counts, haemoglobin concentration and lymphocytes, while mean corpuscular haemoglobin concentration, mean corpuscular volume, neutrophils, monocytes and eosinophils all increased. Collectively, the decrease in the erythrocyte count and haemoglobin content recorded in the present work indicated that metalaxyl-treated mice were anaemic. According to[19], this anaemia is due to (a) increased blood as a result of the accelerated red cell destruction by haemolytic agents or rapid cell removal from an abnormality of cell shape or over-activity of the spleen (b) a quantitative decrease in blood formation as a result of a quantitative decrease in red marrow from aplasia or a quantitative decrease in marrow activity from a deficiency in the substances necessary for normal bone marrow activity.

Table 1. Effect of metalaxyl on blood parameters of male mice

\begin{tabular}{|c|c|c|c|}
\hline \multirow[b]{2}{*}{ Parameters } & \multicolumn{3}{|c|}{ Treatment } \\
\hline & Four weeks & Two weeks & Control \\
\hline $\mathrm{RBCs} 10^{6} / \mathrm{mm}^{3}$ & $5.2 \pm 0.24$ & $4.6 \pm 0.35$ & $4.1 \pm 0.6^{*}$ \\
\hline $\mathrm{Hb} \mathrm{gm} / \mathrm{dl}$ & $11.5 \pm 2.3$ & $10.6 \pm 1.4$ & $9.8 \pm 1.2^{*}$ \\
\hline Platelets $10^{3} / \mathrm{L}$ & $543 \pm 15.3$ & $411 \pm 23$ & $320 \pm 11.9^{*}$ \\
\hline WBCs $10^{6} / \mathrm{mm}^{3}$ & $5.8 \pm 0.4$ & $6.5 \pm 0.6$ & $8.9 \pm 0.8^{*}$ \\
\hline
\end{tabular}

The results in figures 1 and 2 revealed that total proteins and albumin decreased in metalaxyl-treated animals. 
Similarly,[3] and[20] reported that mancozeb fungicide at doses of 600,700 and $800 \mathrm{mg} / \mathrm{kg} /$ day induced a significant decrease in the level of glycogen and protein content in rats.[4] reported that lambda-cyhalothrin-intoxicated rabbits showed increases in their total proteins and albumin in serum.

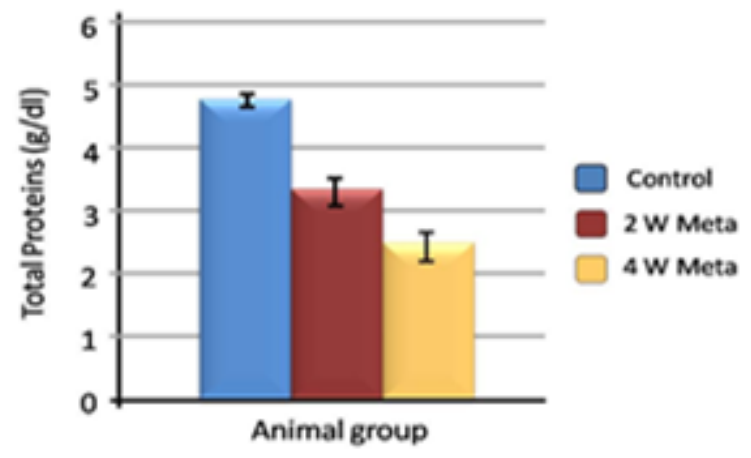

Figure 1. Effect of metalaxyl on total proteins

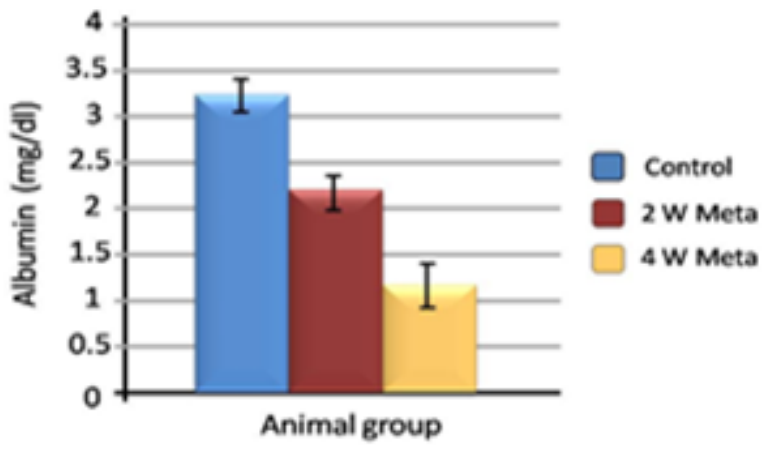

Figure 2. Effect of metalaxyl on total albumin

A significant increase in triglyceride and cholesterol levels was recorded in the sera of mice treated with metalaxyl (Figs. 3 and 4). This result was confirmed by the reports of other authors who obtained similar results with treatments using some fungicides. It was reported that acute thiram (tetramethyl-bis-thiocarbamyl disulphide) poisoning caused decreased lipoprotein lipase (LPL) activity in adipose tissue and increased the levels of total plasma cholesterol, triacylglycerols and high density lipoprotein (HDL) cholesterol in the affected rats[33].[15] also showed that the levels of plasma glucose, triglycerides, cholesterol, creatinine, alanine aminotransferase (ALT), aspartate aminotransferase (AST), liver glycogen and total lipids were elevated in rats treated with carbendazim. It has been speculated that treating mice with metalaxyl increased the degree of tissue lipogenesis and that this increase was most likely achieved through the acceleration of acetyl-CoA, which is known to be the precursor of cholesterol biosynthesis[26]. The present results also showed a significant increase in serum creatinine in response to metalaxyl toxicity (Fig. 5). Similarly,[40] reported that thiophanate-methyl fungicide caused an increase in blood urea nitrogen (at 75, 200, and $1200 \mathrm{ppm}$ ) and creatinine levels (at $1200 \mathrm{ppm}$ ) in rats. This significant rise in creatinine levels was observed in the serum of the male Swiss albino mice after their 4th week of exposure to thimet[21]. The increase in creatinine might be due to impaired kidney function caused by the fungicide. This view was supported by[16], who indicated that an elevation of creatinine level in the blood is an indicator of impaired kidney function.

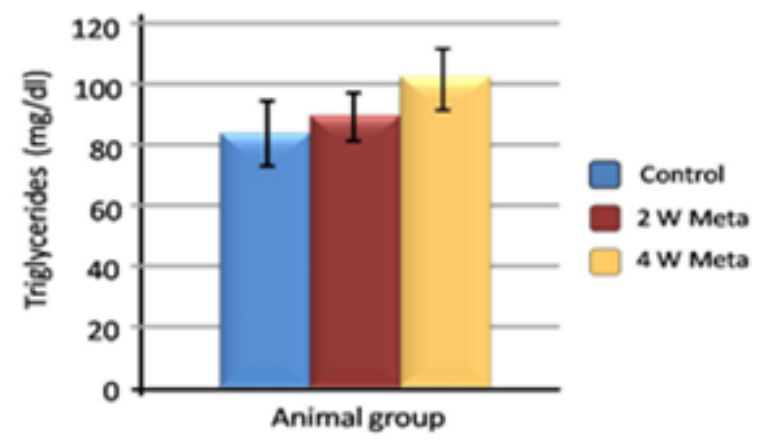

Figure 3. Effect of metalaxyl on triglycerides

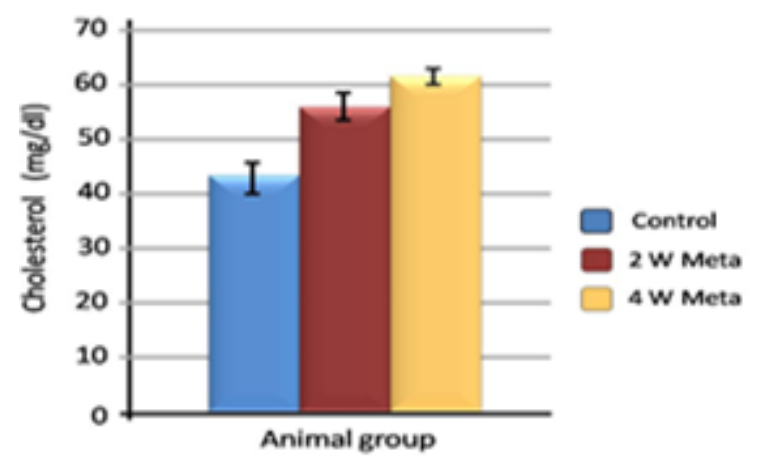

Figure 4. Effect of metalaxyl on cholesterol

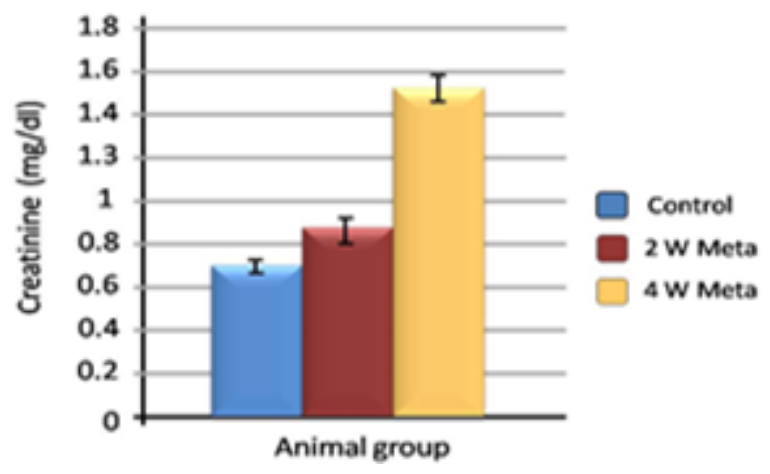

Figure 5. Effect of metalaxyl on creatinine

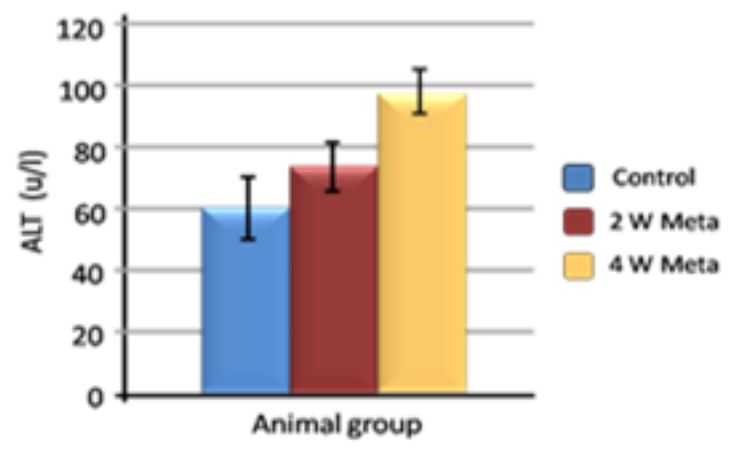

Figure 6. Effect of metalaxyl on ALT

The data in figures 6 and 7 revealed a significant increase in transaminase (ALT and AST) levels in the sera of 
metalaxyl-treated mice. A similar result was obtained by[37]. Other fungicides affected the serum level of transaminase.[17] reported that the fungicide bithionol sulfoxide caused hepatotoxicity, including an increase in serum AST, at high doses $(50,500$ and $1000 \mathrm{mg} / \mathrm{kg})$.[27] also reported that the oral administration of mancozeb (500, 1000 and $1500 \mathrm{mg} / \mathrm{kg} /$ day for 90,180 and 360 days) to male rats induced changes in the activities of ALT and AST throughout the period of the study in a dose-dependent manner. Elevations in the serum levels of these enzymes were mostly attributed to acute hepatocellular damage, extrahepatic obstruction, or both[38].

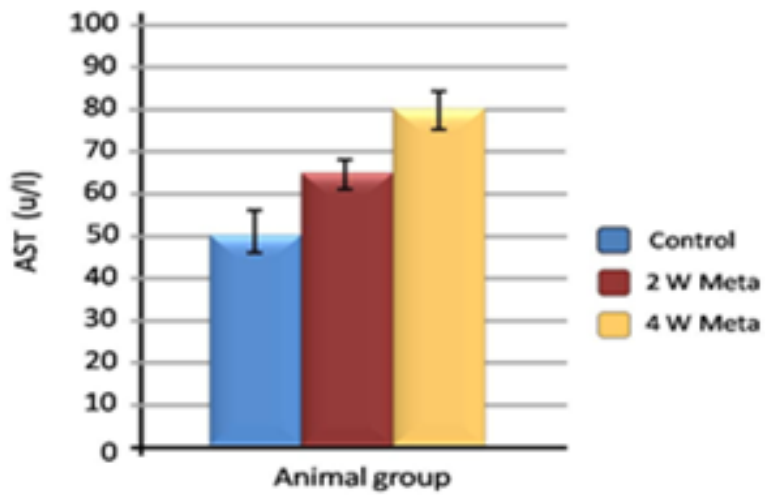

Figure 7. Effect of metalaxyl on AST

Reactive oxygen species (ROS) are constantly produced during the metabolic processes of all living species[33]. Under normal physiological conditions, cellular ROS generation is counterbalanced by the action of antioxidant enzymes and other redox molecules. Oxidative stress is potentially harmful to cells, and reactive oxygen species (ROS) are produced as a reaction to pesticide toxicity, including fungicide exposure. In this regard,[34] reported that metalaxyl induced a significant increase in oxidative stress and malondialdehyde, which is a lipid peroxidation marker, and caused a significant decrease in the level of serum antioxidant enzymes, namely, superoxide dismutase and catalase in mice.[2] found that benomyl caused an increase in serum hydroperoxide and a decrease in reduced glutathione levels in rats.[6] reported that fungicide-induced damage is closely associated with an increase in lipid peroxidation and a decrease in antioxidant enzymes. The results from the above-mentioned authors indicated that metalaxyl induced oxidative stress in mice, which in turn led to observable toxicity.

\section{Conclusions}

Metalaxyl exposure leads to abnormal haematological and biochemical activities as well as induced oxidative stress in mice, which in turn leads to observable toxicity. Treating mice with metalaxyl for 2 and 4 weeks induced a significant decrease in RBC counts, haemoglobin content and the number of blood platelets. In contrast, the effects of metalaxyl led to a significant increase in WBC counts.
Serum triglyceride and cholesterol levels were also increased while total proteins and albumin were decreased in the treated animal. Additionally, metalaxyl exposure led to a significant increase in the production of transaminases, ALT and AST enzymes.

The results also revealed a significant increase in serum creatinine levels in response to metalaxyl toxicity, which might be due to kidney function impairment by the fungicide that was used for this study. It is concluded that these metalaxyl effects may be attributed to induced oxidative stress, which in turn led to the toxicity that was recorded in this article. This interpretation was confirmed by other authors who obtained similar results from studying the effects of fungicides within the same class. The present study suggests that fungicides must be examined for their possible adverse effects on animals and humans before their application to agricultural fields.

\section{REFERENCES}

[1] Auletta C S "A chronic (1-year) oral toxicity study in the dog via capsule administration with thiophanate-methyl" Unpublished report Project No. 89-3526, 1992

[2] Banks D. and Soliman M R I "Protective effects of antioxidants against benomyl-induced lipid peroxidation and glutathione depletion in rats" Toxicology, vol.116, no.1-3, pp 177-181, 1997.

[3] Baligar P N and Kaliwal B B "Induction of gonadal toxicity to female rat after cronic exposure to mancozeb" Ind. Health, vol.39, no.3, pp.235- 243, 2001.

[4] Basir A, Khan A, Mustafa R, Khan M Z, Rizvi F, Mahmood F, Yousaf A "Toxicopathological effects of lambda-cyhalothrin in female rabbits (Oryctolagus cuniculus)".Hum Exp Toxicol. vol.30 no.7 pp.591-602, 2011.

[5] Caldas E D, Miranda M C C and Conceicao, M H "Dithiocarbamates residues in Brazilian Food and potential risk for consumers" J Food Chem Toxicol. vol.42 pp.1877-1883, 2004.

[6] Calviello G, Piccioni E, Boninsegan A, Tedesco B, Maggiano $\mathrm{N}$, Serini S, Wolf F I and Palozza P "DNA damage and apoptosis induction by the pesticide mancozeb in rat cells: involvement of oxidative mechanism" Carcinogenesis. Vol.28, no.6, pp.1202-1209, 2006.

[7] Dasgupta S, Banerjee K, Dhumal K N and Adsule P G. "Optimization of detection conditions and single-laboratory validation of a multiresidue method for the determination of 135 pesticides and 25 organic pollutants in grapes and wine by gas chromatography time-of-flight mass spectrometry" J AOAC Int. vol.94, no.1, pp.273-85, 2011.

[8] Dacie J V and Lewis S M "Practical Haematology". 6th edition. Churchill Livingstone. Edinburgh. London. Melbourne and New York, 1984.

[9] Demsia G, Vlastos D, Goumenou M and Matthopoulos DP "Assessment of the genotoxicity of imidacloprid and metalaxyl in cultured human lymphocytes and rat 
bone-marrow" Mutat Res. Vol.634,no.1-2, pp.32-9, 2007.

[10] Ding F, Li XN, Diao JX, Sun Y, Zhang L, Sun Y" Chiral recognition of metalaxyl enantiomers by human serum albumin: evidence from molecular modeling and photophysical approach" Chirality. Jun;24(6):471-80,2012.

[11] Fossati R and Prenciple L "Serum triglycerides determined colorimetrically with an enzyme that produces hydrogen peroxide" Clin Chem . vol.28, pp.2077-2080, 1982.

[12] Hashimoto Y, Makita T, Nishibe T, Mori T, Ohnuma, N, Noguchi $\mathrm{T}$ and Ohta $\mathrm{G}$ "Subacute toxicity of thiophanatemethyl in mice and rats" Pharmacometrics vol.7, pp.929-945, 1973.

[13] Henry R J "Clinical chemistry. Principles and Techniques" $2^{\text {nd }}$ Edition. Harper and Row, 1974.

[14] Hrelia P, Maffei F, Fimognari C, Vigagni F, Cantelli-Forti G "Cytogenetic effects of Metalaxyl on human and animal chromosomes" Mutat Res. Vol.369, no.1- 2, pp.81-86, 1996.

[15] Kluwe W "Renal function tests as indicators of kidney injury in subacute toxicity" Toxico Appl Pharm vol.57,pp.414-424, 1981.

[16] Lavric A, Skubic V, Senk L, Lukance G. and Kacl E "Oral toxicity of bithionol sulfoxide in mice and rats" Zbornik.Veterinarske. Fakultete. Univerza. Lyublzana, vol.27, no.1, pp.33- 39, 1990.

[17] Lowry O H, Rosenbrough N J and Randall R J "Protein measurements with folin phenol reagent" J. Biol. Chem. Vol.193, pp.265-267, 1951.

[18] Lu F "Basic toxicology, fundamentals, target organs and risk assessment" Hemisphere Publishing Co. Washington. 1981.

[19] Mehadevaswami M P, Jardaramkunti U C, Hiremath, M B and Kaliwal B B "Effect of mancozeb on ovarian compensatory hypertrophy and biochemical constituents in hemicastrated albino rat" Reprod. Toxicol. vol. 14, no.2, pp.127-137, 2001.

[20] Mohssen M "Biochemical and histopathological changes in serum creatinine and kidney induced by inhalation of Thimet (Phorate) in male Swiss albino mouse, Mus musculus" Environmental Res. Vol.87, no.1, pp. 31-36, 2000.

[21] Muthuviveganandavel V, Muthuraman P, Muthu S, Srikumar $\mathrm{K}$."Toxic effects of carbendazim at low dose levels in male rats" J Toxicol Sci. vol.33, no.1, pp.25-30, 2008.

[22] Naidu K A and Radhakrishnamurty R "Metalaxyl-induced bradycardia in rats: mediated by alpha-adrenoreceptors" J Toxicol Environ Health. vol.23, no.1,pp.495-8, 1988.

[23] National Research Council "Guide for use and care of laboratory animals" Publication no.85-23, Wasnington, NIH, 1985.

[24] Paolini M, Mesirca R, Pozzetti L, Sapone A and Cantelli-Forti "Biomarkers of effect in evaluating metalaxyl cocarcinogenesis Selective induction of murine CYP $3 \mathrm{~A}$ isoform" Mutat Res. vol.361, no.2-3, pp.157-164, 1996.

[25] Ray D E and Cremer J E "The action of decamethrin (a synthetic pyrethroid) on the rat" Pestic Biochest. Physiol. vol.10, pp.333-340, 1978 .
[26] Reena-Kackar, Srivastava M K., Raizada R B and Kackar, R "Assessment of toxicological effects of mancozeb in male rats after chronic exposure" Indian J. Exp. Bio vol..37 no.6, pp.553-559, 1999.

[27] Reitman S and Frankel S "Colorimetric determination of glutamic oxaloacetic and glutamic pyruvite transaminase" J. Clin. Pathol. pp. 28-56, 1975.

[28] Rekanović E, Potočnik I, Milijašević-Marčić S, Stepanović M, Todorović B, Mihajlović M." Toxicity of metalaxyl, azoxystrobin, dimethomorph, cymoxanil, zoxamide and mancozeb to Phytophthora infestans isolates from Serbia" J Environ Sci Health B. 47(5):403-9, 2012

[29] Richmond W "Preparation and properties of a cholesterol oxidase from Nocardia $s p$. and its application to the enzymatic assay of total cholesterol in serum" Clin. Chem. vol.19, pp.1350-1356, 1973.

[30] Sadurska B and Boguszewski B "Changes in lipoprotein lipase activity and plasma liver lipids in thiram intoxicated rats". Acta Biochim Pol. vol.40,no.4,pp.563-570, 1993.

[31] Sahu S C "Role of oxygen free radicals in the molecular mechanisms of carcinogenesis: a Review" J. Environ. Sci. Health vol. 9,pp. 83-112, 1991.

[32] Sakr S A and Lamfon H A "Metalexyl fungicide induced oxidative stress and apoptosis in mouse thymus: The effect of antox" Int. J. Immunological Studies, vol.1, no.2, pp.135-149, 2010 .

[33] Sakr S A, Abel-Samie H A "Apoptosis related protein Bax in liver of metalaxyl fungicide -treated mice: The effect of antox" Ozean J Appl Science, vol. 1, no.1, pp.17-27, 2008.

[34] Sakr S A "Ameliorative effect of ginger (Zingiber officinale) on mancozeb fungicide induced liver injury in albino rats" Australian J. Basic Appl.Sci. vol.14, pp. 650-656, 2007.

[35] Sakr S A and Lamfon H A "Effect of green tea on metalaxyl fungicide induced liver injury in albino mice" Oxford Res.Forum J. vol.2, no.2,pp. 65-69, 2005.

[36] Sherlock S "Diseases of the liver and biliary system" .8th ed. Oxford, Blackwell Scientific Publication,1981.

[37] Sukul P, Spiteller M " Metalaxyl: persistence, degradation, metabolism, and analytical methods" Rev Environ Contam Toxicol vol. 164, pp.1-26, 2000.

[38] Takaori H. (1993): "Thiophanate-methyl combined chronic toxicity/oncogenicity study in rats" Unpublished report No. RD-9327 from Nisso Institute for Life Sciences, Kanagawa, Japan. Submitted to WHO by Nippon Soda Co. Ltd, Tokyo, Japan, 1993.

[39] Walker M M and Keith H L "U.S. Environmental Protection Agency's Pesticide Fact Sheet Database". Lewis Publishers, Chelsea, MI, 1992.

[40] Zari T A and Al-Attar A M "Therapeutic effects of olive leaves extract on rats treated with a sublethal concentration of carbendazim" .Eur Rev Med Pharmacol Sci.vol.15, no.4, pp.413-26, 2011. 